\title{
DIRASAH
}

Volume 2, Number 2, Agustus 2019

p-ISSN: 2615-0212 | e-ISSN: 2621-2838

https://ejournal.iaifa.ac.id/index.php/dirasah

\begin{tabular}{|l|c|c|}
\hline Accepted: & Revised: & Published: \\
Maret 2019 & Juli 2019 & Agustus 2019 \\
\hline
\end{tabular}

\section{Pengelolaan Media Pembelajaran dalam Upaya Meningkatkan Hasil Belajar Siswa}

\author{
Mustajib \\ Institut Agama Islam Faqih Asy'ari Kediri, Indonesia \\ e-mail:moestajib86@gmail.com
}

\begin{abstract}
Management of instructional media in an effort to improve student learning outcomes in MAN krecek Pare. The purpose of this study were: (1) to describe how teachers plan the development of instructional media in MAN krecek Pare, (2) to determine the organization of the development of instructional media in MAN krecek Pare, (3) to find out how the implementation of the development of instructional media in MAN krecek Pare, (4) to find out how controlling the development of instructional media in MAN krecek Pare Kediri. This study uses qualitative research field with a descriptive-analytic analysis techniques. Collecting data using observation method, interview method and the method of documentation.Data analysis was performed through three stages which include: data reduction, data presentation and conclusion / verification. RESULTS: (1) Using the learning media there are many benefits, among others: (a) learning with instructional media to facilitate and improve the quality of learning, (b) Improve student learning outcomes, (c) Support individual learning according to the ability of students, $(d)$ can be used as a transmitter of direct feedback, $(e)$ the material can be repeated as needed, without causing boredom. Management of instructional media in MAN krecek Pare able to improve perestasi student learning, and this is because by using instructional media students more interested and more motivated, besides using instructional media students who are slow in the power of acceptance can adjust, with their learning program interactive, students can work on the exercises Saol without depending on the teacher, the learning media.
\end{abstract}




\section{Pendahuluan}

Belajar adalah sesuatu yang sangat kompleks yang terjadi pada diri setiap orang sepanjang hidupnya. Proses belajar itu terjadi karena adanya interaksi antara seseorang dengan lingkungannya. Oleh karena itu, belajar dapat terjadi kapan saja dan di mana saja. Salah satu pertanda bahwa seseorang itu telah belajar adalah adanya perubahan tingkah laku pada diri orang itu yang mungkin disebabkan oleh terjadinya perubahan pada tingkat pengetahuan, keterampilan, atau sikapnya.

Apabila proses belajar itu diselenggarakan secara formal di sekolahsekolah, tidak lain ini dimaksudkan untuk mengarahkan perubahan pada diri siswa secara terencana, baik dalam aspek pengetahuan, keterampilan, maupun sikap. Interaksi yang terjadi selama proses belajar tersebut dipengaruhi oleh lingkungannya, yang antara lain terdiri atas murid, guru, petugas perpustakaan, kepala sekolah, bahan atau materi pelajaran (buku, modul, selebaran, majalah, rekaman video atau audio, dan yang sejenisnya), dan berbagai sumber belajar dan fasilitas (proyektor, overhead, perekam pita audio dan video, radio, televisi, komputer, perpustakaan, laboratorium, pusat sumber belajar, dan lain-lain). ${ }^{1}$

Mengajar merupakan suatu kegiatan yang memerlukan keterampilan profesional. Karena dalam interaksi pembelajaran seorang guru sebagai pengajar akan berusaha secara maksimal dengan menggunakan keterampilan dan kemampuannya agar anak dapat mencapai tujuan yang diharapkan. Untuk dapat mencapai keberhasilan dalam pembelajaran perlu dilakukan sebuah pengelolaan yang baik, yang menuntut seorang guru untuk dapat mengondisikan kelas dan bertanggung jawab di dalam kelas.

Menurut Suharsimi Arikunto, Pengelolaan merupakan terjemahan dari kata "Management", istilah Inggris tersebut lalu di Indonesiakan menjadi "Manajemen" atau "Menejemen". Arti lain dari pengelolaan adalah penyelenggaraan atau pengurusan agar sesuatu yang dikeloladapat berjalan dengan lancar, efektif dan efisien. ${ }^{2}$

Menurut Abdul Majid pengelolaan pembelajaran merupakan suatu proses penyelenggaraan interaksi peserta didik dengan pendidik dan sumber belajar pada suatu lingkungan belajar, salah satu kompetensi yang harus dimiliki oleh

\footnotetext{
${ }^{1}$ Azhar Arsyad, Media Pembelajaran (Jakarta: Rajawali Pers, 2015), 1.

${ }^{2}$ Suharsimi Arikunto, Pengelolaan Kelas dan Siswa Sebuah Pendekatan (Jakarta: CV. Rajawali, 1996), 7-8.
}

Dirasah, Vol. 2, No. 2, Agustus 2019 


\section{Pengelolaan Media Pembelajaran dalam Upaya Meningkatkan Hasil Belajar Siswa}

guru ialah kompetensi dalam pengelolaan pembelajaran yang mencakup: (1) penyusunan perencanaan pembelajaran; (2) pelaksanaan interaksi belajar mengajar; (3) penilaian prestasi belajar peserta didik; (4) pelaksanaan tindak lanjut hasil penilaian. ${ }^{3}$

Berdasarkan pengertian dari efektivitas dan pengelolaan pembelajaran dapat diambil kesimpulan bahwa efektivitas pengelolaan pembelajaran adalah suatu usaha yang dilakukan oleh seorang guru dalam proses belajar mengajar dimulai dari proses perencanaan, pelaksanaan, penilaian pembelajaran dan umpan balik yang memungkinkan kegiatan pengelolaan pembelajaran dapat berlangsung dengan baik sehingga tujuan pembelajaran dapat tercapai.

Pengelolaan kelas dan media pembelajaran siswa merupakan satu kesatuan yang mampu mempengaruhi keberhasilan siswa dalam belajar yaitu pencapaian prestasi. Prestasi belajar merupakan hasil belajar yang diperoleh setiap anak atau siswa setelah kegiatan belajar. Prestasi belajar merupakan bagian akhir dari proses belajar atau dengan kata lain tujuan dari belajar adalah mendapat prestasi. Dengan kata lain prestasi belajar peserta didik dapat ditingkatkan dengan menciptakan pengelolaan kelas yang kondusif.

Seorang guru dituntut untuk mempunyai berbagai keterampilan yang mendukung tugasnya dalam mengajar. Salah satu keterampilan tersebut adalah bagaimana seorang guru dapat menggunakan media pembelajaran. ${ }^{4}$ Guru dapat membuat kreasi dan variasi media interaktif, pembuatan CD pembelajaran interaktif, powerpoint, dan dengan media komputer.

Salah satu upaya seorang guru untuk meningkatkan mutu pendidikan adalah penggunaan media pembelajaran yang tepat dalam menyampaikan pesanpesannya. Hal ini diperuntukkan bagi siswa yang belum dapat menerima pesan yang disampaikan guru, maka penggunaan media sangat dianjurkan. Dengan demikian penggunaan media untuk menyampaikan pesan pembelajaran akan lebih dihayati tanpa menimbulkan kesalahpahaman bagi keduanya yaitu murid dan guru.

Media kini sudah banyak sekali dijadikan sebagai basis pembelajaran karena terbukti media dapat melengkapi dan mendukung kegiatan interaksi pendidik dalam kegiatan pembelajaran. Media sendiri secara istilah dapat

\footnotetext{
${ }^{3}$ Abdul Majid, Perencanaan Pembelajaran (Bandung: Rosda Karya, 2007), 6 \&111.

${ }^{4}$ Syaiful Bahri Djamarah dan Aswan Zein, Strategi Belajar Mengajar (Jakarta: Rineka Cipta, 2006), 164.
} 
diartikan sebagai alat atau sarana komunikasi. ${ }^{5}$ Dengan jenisnya yang multifungsi dapat pula disesuaikan dengan berbagai metode pembelajaran yang akan diterapkan. Sekarang banyak sekolah yang sedangmengembangkan media pembelajaran sebagai penunjang meningkatkan hasil belajar siswa-siswinya.

Seperti halnya yang sedang diterapkan oleh Madrasah Aliyah Negeri (MAN) Krecek Kecamatan Pare Kabupaten Kediri. MAN Krecek sebagai sekolah berciri khas Islam tingkat menengah atas, juga sedang mengupayakan peningkatan mutu pembelajaran, yang salah satunya dengan memperbaiki proses pelaksanaan pembelajaran. Sekolah ini memandang bahwa hasil pembelajaran yang sedang berlangsung belum berdaya saing cukup baik jika dibandingkan dengan sekolah-sekolah unggulan, terutama beberapa sekolah Islam yang ada di wilayah Pare dan Kandangan. Untuk mewujudkan hal itu, maka para pendidik dianjurkan untuk mengupayakan hasil belajar siswasiswinya yang ditunjang dengan memaksimalkan penggunaan media pembelajaran.

Dalam hal ini sekolah MAN Krecek telah berupaya untuk menyediakan sarana pembelajaran untuk mendukung out put yang handal dan siap bersaing dengan memaksimalkan pemanfaatan / pengelolaan media pembelajaran di MAN Krecek. Sarana pembelajaran yang kini sudah tersedia yakni berupa ruang lab Komputer, yang mana di dalamnya terdapat media berupa komputer yang jumlahnya ada 70 unit, yang diperuntukkan siswa dalam pengembangan kemampuan siswa di bidang teknologi dan komunikasi. Sekolah juga menyediakan 6 unit LCD Projector yang terdapat di kelas XII, dapat digunakan guru sebagai media pengantar pembelajaran dengan menggunakan Laptop. ${ }^{6}$ Dengan sudah tersedianya sarana dan media pembelajaran tersebut, maka pendidik diharapkan dapat mengelola danmenerapkan media pembelajaran secara maksimal.

Berdasarkan atas permasalahan yang telah diuraikan diatas, maka peneliti merasa tertarik untuk meneliti lebih dalam tentang proses pembelajaran yang berlangsung di MAN Krecek, yang mengupayakan hasil belajar siswa-siswinya dengan mengelola media pembelajaran yang ada. Dengan demikian fokus dari penelitian ini adalah "Pengelolaan Media Pembelajaran Dalam Upaya meningkatkan hasil belajar siswa di MAN Krecek, Pare-Kab.Kediri”.

\footnotetext{
5 Ibid., 314.

${ }^{6}$ Wawancara dengan sebagian siswa MAN Krecek, 14 Januari 2016
}

Dirasah, Vol. 2, No. 2, Agustus 2019 


\section{Metode Penelitian}

\section{Desain penelitian}

Metode penelitian dapat diartikan sebagai cara ilmiah untuk mendapatkan data yang valid dengan tujuan dapat ditemukan, dikembangkan, dan dibuktikan, suatu pengetahuan tertentu sehingga pada gilirannya dapat digunakan untuk memahami, memecahkan, dan mengantisipasi masalah dalam bidang pendidikan. $^{7}$

Penelitian ini menggunakan pendekatan fenomenologis. Karena terkait langsung dengan gejala-gejala yang muncul di sekitar lingkungan manusia terorganisir dalam satuan pendidikan formal.

Sedangkan jenis penelitian yang dipakai adalah penelitian kualitatif grounded (penelitian lapangan). Penelitian kualitatif grounded adalah prosedur penelitian yang menghasilkan data deskriptif berupa kata tertulis atau lisan dari orang-orang yang perilakunya dapat diamati. ${ }^{8}$

\section{Subyek Penelitian}

Subyek penelitian dipilih berdasarkan metode purposive sampling yaitu teknik pengambilan sampelsumber data dengan pertimbangan tertentu. ${ }^{9}$ Maksud dari penentuan sampel dalam hal ini adalah untuk menjaring informasi sebanyak mungkin dari berbagai macam sumber dan bangunannya (contructions). ${ }^{10}$ Adapun yang akan menjadi subyek dalam penelitian ini antara lain:

1. guru

Yang mana nantinya responden terkait akan kami wawancarai mengenai penggunaan media belajar, jenis media, evaluasi setelah dan sebelum penggunaan media, dll.

2. para siswa

Para siswa diberi lembaran kertas yang mana di dalamnya ada beberapa pertanyaan terkait pembelajaran yang menggunakan media pembelajaran, pendapat mereka tentang profesionalisme guru dalam menggunakan media pembelajaran, situasi di dalam kelas ketika penggunaan media, dll.

7 Sugiono, Metode Penelitian Pendidikan Pendekatan Kuantitatif, Kualitatif, dan $R \& D$ (Bandung: Alfabeta,2013), 6.

${ }^{8}$ Ibid., 14.

${ }^{9}$ Ibid., 30.

${ }^{10}$ Lexy J. Moleong, Metodologi Penelitian Kualitatif (Bandung: PT Remaja Rosdakarya, 2005), 224. 
3. tata usaha.

Meminta file/dokumen terkait profil sekolah, sarana prasarana, kurikulum, data media pembelajaran yang dimiliki sekolah, dll.

4. kepala sekolah

Peneliti akan berusaha meminta pendapat kepala sekolah terkait: Usaha kepala sekolah dalam pengadaan media pembelajaran, usaha menginstruksikan para guru dalam penggunaan media pembelajaran, dll.

\section{Teknik pengumpulan data}

Dalam pengumpulan data, peneliti memakai dua teknik:

1. observasi

Teknik ini peneliti gunakan untuk memperoleh data tentang bagaimana penggunaan/pengelolaan media pembelajaran dalam upaya meningkatkan hasil belajar siswa di MAN Krecek-Pare. dan bagaimana keadaan sarana dan prasarana di MAN Krecek-Pare dalam menunjang proses pembelajaran.

2. wawancara

Teknik ini peneliti gunakan untuk memperoleh data dari kepala sekolah, waka kesiswaan, waka kurikulum,sarana prasarana, Guru, siswa peserta proses pembelajaran. dan pihak-pihak yang terkait dengan tema yang penulis tentukan.

\section{Teknik analisis data}

Dalam menganalisis data peneliti menggunakan tahapan yaitu:

1. data reduction (pengumpulan data)

Data yang kami peroleh dari lapangan tentulah jumlahnya cukup banyak, untuk itu kami perlu mencatatsecara teliti dan rinci. dan segera melakukan analisis data melalui reduksi data (merangkum data), memilih hal hal yang pokok, memfokuskan pada hal hal yang penting, dicari tema dan polanya.

2. data display (pengklasifikasian data)

Untuk memudahkan kami dalam mengambil data yang diinginkan, kami perlu menyajikan data dalam bentuk uraian singkat, bagan, hubungan antar kategori, dan sejenisnya, pada intinya kami bisa mendapatkan data yang kami inginkan, yang mana ketika sepulang kami dari lapangan, data dapat kami olah kembali. 


\section{Verification(verifikasi)}

Data yang diperoleh dari lapangankemudian dianalisis dengan menggunakan metode kualitatif, artinya mengelompokkan dan menyeleksi data yang diperoleh berdasarkan kualitas kebenarannya kemudian menggambarkan dan menyimpulkan hasilnya untuk menjawab permasalahan yang ada.

Pengumpulan data tentang pengelolaan media pembelajaran dalam upaya meningkatkan hasil belajar siswa MAN Krecek, Pare-Kab.Kediri, dilakukan melalui pengamatan, wawancara dan dokumentasi. Data tersebut meliputi 1) gambaran umum tentang kondisi sekolah/lingkungan sekolah, 2) sejauh mana penggunaan media pembelajaran mampu meningkatkan hasil pembelajaran pada siswa-siswi di MAN Krecek, Pare-Kab. Kediri. 3) sudah efektifkah perencanaan dan pengorganisasian pengembangan media pembelajaran di MAN Krecek, PareKabupaten Kediri.Langkah selanjutnya adalah menyederhanakan, menyusun secara sistematis hal-hal yang pokok dan penting dan membuat abstraksi untukmemberi gambaran yang tajam serta bermakna.

\section{Hasil Penelitian}

\section{Paparan data penelitian}

1. Variabel pengelolaan pembelajaran

Pengelolaan pembelajaran mencakup proses perencanaan, pelaksanaan, penilaian pembelajaran dan tindak lanjut. Berdasarkan wawancara dengan guru bidang ekonomi, al-qur'an hadist dan waka kurikulum, bahwa dalam persiapan pembelajaran, guru membuat silabus dan RPP yang sesuai dengan kurikulum dan dilaporkan setiap awal semester. RPP tersebut sudah mencakup dua semester, yang kemudian silabus dan RPP tersebut dibukukan oleh guru bersama pihak sekolah.

Dari hasil wawancara, tentang keterampilan membuka pembelajaran hal yang bisa dilakukan oleh guru ekonomi adalah menciptakan kesiapan mental dan menarik perhatian siswa secara optimal, agar mereka memusatkan diri sepenuhnya untuk belajar serta memancing keingintahuan siswa terhadap pembelajaran yang akan dilaksanakan.

Dalam hal menyajikan inti pembelajaran, guru ekonomi menggunakan media power point, walaupun sebenarnya masih banyak lagi jenis media yang dapat digunakan pada mata pelajaran tersebut. Ada kendala yang ditemukan 
di sekolah tersebut mengenai penggunaan media pembelajaran, seperti waktu proses pembelajaran yang menggunakan media tiba-tiba listrik padam, ada beberapa unit komputer yang kurang maksimal fungsinya. Akhirnya solusi yang diintruksikan kepada para siswa yaitu dengan membuka laptop pribadi siswa dan bagi yang tidak membawa atau memiliki diminta untuk gabung dengan siswa lainya, jadi siswa membentuk kelompok-kelompok sesuai jumlah laptop yang ada.

Selanjutnya dalam menutup pembelajaran, para guru terlebih dahulu memberikan kesempatan untuk siswa menyimpulkan materi yang telah dibahas, setelah itu baru guru yang menyimpulkan, tidak lupa menanyakan materi yang belum dipahami dan memberikan tugas untuk dikerjakan di rumah.

Dalam evaluasi pembelajaran, yang dilakukan untuk mengetahui ketercapaian kompetensi siswa pada setiap selesai pembelajaran adalah dengan mengajukan pertanyaan-pertanyaan seputar materi yang telah dibahas, memberikan soal-soal latihan dan mengadakan ulangan harian. Selanjutnya dalam hal tindak lanjut pembelajaran, guru mengadakan program remedial bagi siswa yang nilainya di bawah rata-rata.

2. variabel hasil belajar

Berdasarkan hasil wawancara dengan guru ekonomi, al-qur'an hadist dan waka kurikulum bahwa hasil belajar siswa itu dapat terlihat ketika ada perlombaan-perlombaan, cara berpakaian para siswa yang semakin rapi dan keingintahuan para siswa waktu proses pembelajaran dengan ajuan makin banyak siswa yang berpartisipasi waktu pembelajaran berlangsung, seperti datang di kelas sebelum guru masuk kelas, banyak pertanyaan-pertanyaan selesai pembelajaran, dan tugas para siswa di rumah yang dikerjakan sesuai jadwal yang ditentukan.

Terlebih waktu penggunaan media pembelajaran, mereka semakin antusias dalam mengikuti pembelajaran dengan ajuan sebagian siswa siap untuk mempersiapkan alat-alat pembelajaran, perhatian pada materi yang disampaikan juga semakin fokus tidak begitu banyak yang bicara sendiri dan selesai pembelajaran mereka meminta soft file kepada guru yang dikoordinir oleh ketua kelas. 


\section{Deskripsi temuan data}

1. Perencanaan pengembangan media pembelajaran di MAN Krecek Pare Kediri

Berdasarkan hasil wawancara dan interview dengan waka kurikulum Bapak Fuat Muzaqqi, S.Pd. M.Si, dan guru Qur'an Hadist bapak Suwarno, S.Ag M.Si, pada tanggal 29 Maret 2016 bertempat di kantor sekolah pukul 09.00-10.00 WIB yang mengacu pada rumusan masalah dapat diperoleh data berikut ini:

a. membuat RPP dan pokok bahasan yang sesuai

Berdasarkan hasil wawancara dengan guru qur'an hadist dapat diungkapkan bahwa:

"...urusan perencanaan pembelajaran yang menggunakan media sebelumnya saya mempersiapkan dulu rencana pelaksanaan pembelajaran, membuat pokok bahasan yang sesuai materi yang akan saya sampaikan, menyiapkan gambargambar yang dicari lewat internet, ditambah dengan keterangan yang lebih mendalam terkait materi yang disampaikan serta mempersiapkan media seperti LCD." 11

b. persiapan sebelum menggunakan media

Sebagaimana yang dikatakan oleh guru bidang ekonomi, Bapak Fuad pada tanggal 29 Maret 2016, bertempat di kantor sekitar pukul 09.40.

Setelah tahap pembuatan RPP dan pokok bahasan sesuai kebutuhan, selanjutnya guru perlu mengetahui apakah media yang akan digunakan dalam pembelajaran sudah dipersiapkan atau belum. Sesuai hasil wawancara dengan pak fuad menyatakan bahwa:

“...biasanya setelah selesai dengan persiapan pembuatan materi pokok bahasan, saya ngecek media pembelajaran sudah disiapkan atau belum denganmenyerahkan laptop. Media yang akan saya gunakan biasanya sudah tersedia di kelas, tetapi saya hanya memastikan untukmengetahui apakah media dalam keadaan layak pakai ...."12

\footnotetext{
${ }^{11}$ Wawancara dengan Suwarno, selaku guru Qur'an Hadist, tanggal 27 Maret 2016.

${ }^{12}$ Wawancara dengan Fuad, selaku guru bidang ekonomi tanggal 29 Maret 2016.
} 
2. Pengorganisasian pengembangan media pembelajaran di MAN Krecek Pare Kediri

a. professionalism guru dalam menggunakan media

Hasil wawancara dengan waka kurikulum, beliau menyatakan bahwa:

“...kebanyakan guru di MAN Krecek sudah bisa mengoperasikan media pembelajaran sendiri, mempersiapkan materi ajar sendiri danbisa dikatakan $90 \%$ mampu, terbukti mereka banyak yang memiliki laptop pribadi..."13

Hasil observasi menunjukkan bahwa; memang banyak guru yang mengajar menggunakan alat bantu ajar, seperti gambar, slide, power point dll. Tapi ada sebagian guru pada waktu mengoperasikan salah satu media di dalam kelas masih membutuhkan bantuan dari siswa, itupun guru senior (guru sepuh).

b. Media yang memadai

Berdasarkan hasil observasi peneliti, terdapat beberapa jenis media yang digunakan di MAN Krecek Pare Kediri, diantaranya yaitu: LKS, papan tulis, buku paket, laboratorium komputer, LCD Proyektor dan lain sebagainya. Akan tetapi ketika peneliti melakukan wawancara dengan guru ekonomi, Bapak Fuad Muzzaki beliau mengatakan: Penggunaan media atau jenis media yang sering digunakan di MAN Krecek Pare Kediri, yaitu yang dikenal dengan sebutan ruang multimedia.

3. Pelaksanaan pengembangan media pembelajaran di MAN Krecek Pare Kediri a. komunikatif dan partisipasi siswa

Sesuai peryataan dari Bapak Fuad Muzzaki, pengajaran tidak hanya penyampaian materi dan alat penyampai pesan/media lebih dari itu keikutsertaan siswa dalam menanggapi materi yang saya sampaikan itu jauh lebih penting.

“...Sikap aktif dan keikutsertaan anak-anak itu selalu saya tunggu, biar saya tau mereka sudah konsen dengan pelajaran atau belum, terkadang mereka ada di kelas tapi pikirannya keluyuran kemana-mana..."14

\footnotetext{
${ }^{13}$ Wawancara dengan David, selaku wakil kepala kurikulum tanggal 1 Juni 2016.

${ }^{14}$ Wawancara dengan Fuad, selaku guru bidang Ekonomi tanggal 29 Maret 2016.
}

Dirasah, Vol. 2, No. 2, Agustus 2019 
Peryataan serupa juga diutarakan Bapak Suwarno selaku guru Qur'an Hadist

“...Menurut saya, ketika saya menggunakan media pembelajaran banyak siswa yang memperhatikan pelajaran yang saya berikan dan itu pun sangat menarik. alhamdulillah metode yang saya gunakan cukup berhasil menarik perhatian siswa dan proses kegiatan belajar mengajar terlaksana dengan baik..."15

b. Penggunaan media pembelajaran oleh guru

Sebagaimana yang diungkapkan oleh bpk fuad selaku waka kurikulum pada tanggal 29 Maret 2016, bertempat di kantor sekitar Pukul 09.30-10.00 WIB:

“...sekolah ini sudah mengupayakan pengaadaan media pembelajaran untuk membantu guru mengajar dan agar para siswa itu terbiasa dengan teknologi, lebih-lebih bisa menggunakannya dengan baik. Oleh karena itu biasanya ketika rapat saya menyempatkan untuk mengingatkan para guru untuk menggunakan media yang sudah di sediakan oleh sekolah..."16

c. Penggunaan media pembelajaran sesuai materi dan metode

Dari berbagai strategi pelaksanaan pengembangan media, dan metode dalam pengembangan media pembelajaran, guru juga harus menggunakan media pembelajaran sesuai materi dan metode. Seperti yang disampaikan BapakSuwarno, M.Si, bertempat di kantor beliau mengatakan:

“...selain saya membuat materi pokok bahasan yang akan saya sampaikan pada para siswa, saya juga memilih media yang sesuai dengan materi yang saya buat, saya juga menggunakan multimedia presentasiyang mana sebagian siswa saya bentuk dalam kelompok kecil, kemudian mereka mempresentasikan hasil kerja kelompoknya kepada semua siswa dan dilanjutkan dengan Tanya jawab.Presentasi ini biasanya saya menggunakan powerpoint ..."17

\footnotetext{
${ }^{15}$ Wawancara dengan Suwarno, selaku guru Qur'an Hadist pada tanggal 29 Maret 2016.

${ }^{16}$ Wawancara dengan David, selaku wakil kepala kurikulum tanggal 29 Maret 2016.

${ }^{17}$ Wawancara dengan Suwarno, selaku guru Qur'an Hadist, tanggal 29 Maret 2016.
} 
Tidak beda jauh dengan yang dilakukan guru bidang study ekonomi yang menggunakan media pembelajaran ketika situasi dan keadaan siswa lagi loyo, alias di jam-jam terakhir.

“...Terkadang saya memilih media pembelajaranTI sebagai sarana dalam menyampaikan materi pembelajaran jika saya anggap anak-anak membutuhkan suasana yang beda, sebab mampu mengatasi kejenuhan, waktu, dan daya indra serta dapat menimbulkan kegairahan belajar. Selain itu media juga dapat menimbulkan persepsi yang sama". ${ }^{18}$

4. Pengawasan (controlling) pengembangan media pembelajaran di MAN Krecek Pare Kediri

Terkait dengan hal ini ada beberapa hal yang perlu diperhatikan:

a. pengawasan penggunaan media pembelajaran

Mengenai pengawasan pengunaan media secara langsung memang tidak ada, jadi bentuknya hanya berupa pengamatan dari perangkat pembelajaran yang dibuat oleh para guru, misalnya pada pembuatan silabus dan rpp, disitu disebutkan media/alat pembelajaran. Biasanya pengawasan penggunaan media oleh kepala sekolah diintruksikan ketika rapat para guru, dengan harapan media yang ada digunakan sebaik mungkin guna meningkatkan hasil belajar.

“...Dalam RPP setiap guru untuk dicantumkan alat bantu (media) yaitu yang bisa berupa LCD/slide/gambar/dll, dengan tujuan para guru sewaktu mengajar juga menggunakan media pembelajaran yang sesuai tercantum di RPP dan silabus..."19

b. Pengawasan pemeliharaan media pembelajaran

Pemeliharaan media harus mendapat penangganan yang khusus, sebab banyak orang yang menggunakanya, seperti yang diungkapkan oleh waka kurikulum bpk fuad muzzaki, beliau mengatakan bahwa:

“...Dalam menjaga kualitas media tetap prima, hal ini diserahkan kepada bagian sarana prasarana dalam pemeliharaannya, seperti mengecek kondisi media, masih layak pakai atau tidak, menangani/menyiapkan media pembelajaran ketika hendak dipakai dalam event besar seperti

\footnotetext{
${ }^{18}$ Wawancara dengan Fuad, selaku guru bidang studi ekonomi tanggal 29 Maret 2016.

${ }^{19}$ Wawancara dengan Fuad, selaku waka kurikulum tanggal 29 Maret 2016.
}

Dirasah, Vol. 2, No. 2, Agustus 2019 
pertemuan para guru atau rapat maupun dipinjam oleh siswa, dan membuat laporan secara berkala kepada kepala madrasah..." 20

Beliau juga menambahkan.

“...Akan tetapi mengenai pemeliharaan media pembelajaran di sekolah ini kami belum mempunyai petugas/pegawai kusus untuk hal itu, masih diusulkan waktu rapat kerja kemarin..."

\section{Pembahasan Hasil Penelitian}

\section{Perencanaan pengembangan media pembelajaran di MAN Krecek Pare}

\section{Kediri}

Berdasarkan hasil penelitian yang diterapkan di MAN Krecek Pare Kediri dalam perencanaan pengembangan media pembelajaran guru membuat RPP dan pokok bahasan yang sesuai dengan kebutuhan akan diajarkan agar tujuan pembelajaran dapat tercapai, seperti guru terlebih dahulu membuat powerpoint, alat bantu mengajar berupa gambar, slide dan media lain yang diperlukan ketika penyampaiannya.

Sesuai yang dikemukakan oleh Cunningham, menurutnya perencanaan adalah menyeleksi dan menghubungkan pengetahuan, fakta, imajinasi, dan asumsi untuk masa yang akan datang dengan tujuan memvisualisasikan dan memformulasi hasil yang diinginkan, urutan kegiatan yang dilakukan, dan perilaku dalam batas-batas yang dapat diterima yang akan digunakan dalam penyelesaian. ${ }^{21}$

Dari pengamatan peneliti sewaktu observasi bersamaan dengan adanya pembelajaran yang sedang berlangsung, mengenai pemasangan laptop ke proyektor, penempatannya serta arah cahayanya sudah tepat dan jelas, hal demikian membuktikan bahwa perencanaan media pembelajaran sudah baik dan sudah mengenai pada sasaran pembelajaran.

\footnotetext{
${ }^{20}$ Ibid., 15

${ }^{21}$ Hamzah B. Uno, Perencanaan Pembelajaran (Jakarta: PT. Bumi Aksara, 2007), 1
} 


\section{Pengorganisasian pengembangan media pembelajaran di MAN Krecek Pare Kediri}

Pengorganisasian media, dalam hal ini ada beberapa poin yang perlu diperhatikan, diantaranya:

1. professionalism guru dalam menggunakan media

kemampuan guru dalam mengoperasikan media pembelajaran sudah mumpuni dan layak, hampir $90 \%$ para guru mampu menggunakanya dengan baik, meskipun ada beberapa guru yang masih minta bantuan siswanya, itupun hanya guru sepuh. Kelayakan penggunaan media dilihat dari persiapan yang dilakukan oleh guru sebelum menggunakan media mulai dari membuat rpp, membuat pokok bahasan dan juga pemilihan media ajar, serta mengoperasikanya. itu semua sangat menunjang keberhasilan dalam pembelajaran. Sehingga manfaat media dapat tercapai dan materi pelajaran dapat disampaikan dan dipahami oleh siswa.

Seperti yang dikemukakan oleh azhar dalam bukunya guru trampil mengunakan media. Ini merupakan salah satu criteria utama. Apa pun media itu, guru harus mampu menggunakanya dalam proses pembelajaran. Nilai dan manfaat media amat ditentukan oleh guru yang menggunakanya. Proyektor transparansi (OHP), proyektor, slide dan film, computer dan peralatan canggih lainya tidak akan mempunyai arti apa-apa jika guru belum dapat menggunakanya dalam proses pembelajaran sebagai upaya mempertinggi mutu dan hasil belajar. ${ }^{22}$

2. Media yang memadai

Media yang digunakan di MAN Krecek Pare Kediri adalah multimedia projector (LCD), yang mana media tersebut sudah terpasang di setiap kelas XII (6 ruang) di tambah yang ada di kantor yang dapat dipasang ketika diperlukan. Dalam penggunaan media, guru mencoba untuk menggunakan berbagai metode pengajaran dan disesuaikan dengan media yang dipakai. Sesekali para guru juga mengajak para siswa untuk melakukan kegiatan belajar mengajar di lab computer untuk menghindari jenuh dan bosan.

Pemanfaatan multimedia proyektor dalam ini biasanya menggunakan power point. penggunaan power point dengan memanfaatkan LCD Proyektor, siswa menjadi tertarik saat guru menjelaskan materi dengan

22 Azhar Arsyad, Media Pembelajaran (Jakarta: Rajawali Pers, 2015), 75.

Dirasah, Vol. 2, No. 2, Agustus 2019 
power point karena materi yang terdapat dalam power point itu terdapat animasi, penuh warna, simbol atau gambar yang bergerak sehingga menarik perhatian siswa. Penggunaan power point dengan animasi yang menarik perhatian siswa, dapat mengurangi kebosanan siswa terhadap materi pelajaran.

Dalam hal ini guru berupaya untuk menampilkan rangsangan (stimulus) yang dapat diproses dengan berbagai indra. Semakin banyak alat indera yang digunakan untuk menerima informasi semakin besar kemungkinan informasi tersebut dimengerti dan dapat dipertahankan dalam ingatan. Dengan demikian, siswa akan dapat menerima dan menyerap dengan mudah dan baik pesan-pesan dalam materi yang disajikan. ${ }^{23}$

Menurut hemat penulis kelebihan dari menggunakan multimedia power point itu, materi yang disajikan menjadi lebih menarik perhatian siswa dan memfokuskan pikiran mereka pada materi pelajaran, dikarenakan multimedia ini mampu menampilkan objek-objek yang sebenarnya tidak ada secara fisik dan juga memiliki kemampuan dalam menggabungkan semua unsur media seperti teks, video, animasi, image dan grafik.

\section{Pelaksanaan pengembangan media pembelajaran di MAN Krecek Pare Kediri}

Pelaksanaanpengembangan media pembelajaran di MAN Krecek Pare Kediri diantaranya:

1. Komunikatif dan partisipasi siswa

Di MAN Krecek Pare Kediri strategi guru dalam penyampaian materi ketika menggunakan media pebelajaran adalah siswa dibentuk dalam kelompok kecil, kemudian mereka mendiskusikan dan mempresentasikan hasil kerja kelompoknya kepada semua siswa dan dilanjutkan dengan tanya-jawab, hal semacam itu diupayakan guru agar antar siswa terjalin komunikasi timbal balik.

Kaitanya bahwa belajar membutuhkan interaksi, hal ini menunjukan bahwa proses pembelajaran merupakan proses komunikasi, artinya

${ }^{23}$ Ibid., 11. 
didalamnya terjadi proses penyampaian pesan dari seseorang (sumber pesan) kepada seseorang atau sekelompok orang (penerima pesan) ${ }^{24}$

Partisipasi aktif oleh siswa jauh lebih baik daripada mendengarkan dan menonton secara pasif. Partisipasi artinya kegiatan mental atau fisik yang terjadi di sela-sela penyajian materi pelajaran. Dengan partisipasi kesempatan lebih besar terbuka bagi siswa untuk memahami dan mengingat materi pelajaran itu. ${ }^{25}$

Jadi menurut penulis antara komunikasi dengan partisipasi siswa adalah suatu keharusan yang ada dalam proses pembelajaran, kalau seorang guru sudah bisa menyampaikan materi dengan baik, mengamati para siswanya dengan seksama saya yakin hasil pembelajaran yang sudah dicanangkan akan cepat tercapai.

2. Penggunaan media oleh guru

Dalam proses pembelajaran tidak sedikit dari mereka yang menggunakan media sebagai penunjang keberhasilan proses belajar mengajar, Akan tetapi guru dalam menggunakan media acuanya tetap pada pokok bahasan yang sesuai dengan kebutuhan, jadi tidak setiap pembelajaran guru di MAN Krecek harus menggunakan media berbasis teknologi, terkadang hanya metode ceramah dan cerita saja.

3. Penggunaan media sesuai materi dan metode

Selain mengembangkan media pembelajaran yang sudah ada, para guru juga mengembangkanmetode pembelajaran yang sifatnya strategi, yaitu selesai penjelasan materi ajar dengan menggunakan media pembelajaran, para guru meminta para siswanya untuk mendemonstrsikan ulang, dengan harapan guru dapat menilai apakah materi yang disampaikan dapat diterima dengan baik.

Di samping itu, guru dalam menggunakan media pembelajaran juga menggunakan metode yang sesuai dengan materi yang akan disampaikan. Sebagai contoh ketika meteri tersebut tentang surat atau ayat-ayat AlQuran, maka ditekankan praktek, yang mana siswa dituntut untuk bisa menulis, membaca dan menghafal, dan ketika hadist tentang akhlaq atau kisah-kisah

\footnotetext{
${ }^{24}$ Rudi Susila dan Cepi Riyana, Media Pembelajaran Hakikat, Pengembangan, Pemanfaatan Dan Penilaian (Bandung; Wacana Prima 2009), 2.

${ }^{25}$ Ibid., 73.
}

Dirasah, Vol. 2, No. 2, Agustus 2019 
maka disitu menggunakan metode ceramah. Jadi tidak semua penggunaan media pembelajaran digunakan pada semua materi.

Dari pembahasan diatas dapat diambil kesimpulan bahwa kriteria dalam pemilihan mediadisesuaikan dengan tujuan pembelajaran atau kompetensi yang ingin dicapai. Misalnya, bila tujuan atau kompetensi peserta didik bersifat menghafalkan kata-kata tentunya media audio yang tepat digunakan. Jika tujuan atau kompetensi yang dicapai bersifat memahami isi bacaan maka media cetak yang lebih tepat digunakan. Kalau tujuan pembelajaran bersifat gerak dan aktivitas, maka media film dan video yang digunakan.

Media pembelajaran memiliki beberapa nilai praktis diantaranya: ${ }^{26}$

1. Media pembelajaran dapat mengatasi perbedaan pengalaman siswa

2. Media pembelajaran dapat membangkitkan semangat belajar yang baru dan membangkitkan motivasi serta merangsang kegiatan siswa dalam belajar

3. Media pembelajaran dapat mempengaruhi abstraksi

4. Media pembelajaran dapat memperkenalkan, memperbaiki, meningkatkan, dan memperjelas pengertian konsep dan fakta

5. Media dapat membantu mengatasi keterbatasan indera manusia

6. Media dapat mengatasi kendala keterbatasan ruang dan waktu

7. Media dapat menyajikan obyek pelajaran berupa benda atau peristiwa langka dan berbahaya ke dalam kelas

Dari hasil pengamatan terbukti implementasi penggunaan media sudah cukup baik. sebagaimana bukti para peserta didik mampu mengapresiasikan kesan-kesan pembelajaran dikelas yang merasa puas dengan layanan sekolah dan faham atas apa yang disampaikan oleh guru dari materi pelajaran yang disampaikan.

\section{Pengawasan (Controlling) pengembangan media pembelajaran di MAN Krecek Pare Kediri}

Pengawasan media pembelajaran di MAN Krecek Pare Kediri dilakukandengan dua cara, pertama pengawasan pengunaan media pembelajaran, disekolah ini bentuk pengawasanya yaitu berupa pengamatan dari

26 Aristo Rahadi. Media Pembelajaran (Jakarta: Depdiknas Dirjend Pendidikan Dasar dan Menengah Direktorat Tenaga Kependidikan, 2003), 18-19.

Dirasah, Vol. 2, No. 2, Agustus 2019 
silabus dan rpp guru, dengan kata lain waka kurikulum dapat mengetahui guru mana yang memakai media pada perangkat pembelajarannya, sebab sudah diintruksikan dibeberapa pertemuan seperti rapat 3 wulan.

Menurut hemat peneliti pengawasan penggunaan media itu sebaiknya lebih ditekankan supaya guru dan siswa mendapat pengetahuan dan pengalaman baru, seperti yang dikemukakan oleh (Azhar) dalam bukunya media pembelajaran beliau berpendapat bahwa penggunaan media itu diperlukan agar pemerolehan pengetahuan dan keterampilan, perubahan-perubahan sikap dan perilaku dapat terjadi karena interaksi antara pengalaman baru dengan pengalaman yang pernah dialami sebelumnya. ${ }^{27}$

Kedua, berupa pemeliharaan dan perbaikan media yang ada, media pembelajaran berbasis teknologi informasi dan komunikasi memang rentan mengalami kerusakan sehingga dalam menggunakan media tersebut harus memperhatikan beberapa teknik agar media yang dipergunakan itu dapat dimanfaatkan dengan maksimal dan tidak menyimpang dari tujuan media tersebut. Oleh karena itu, dalam penggunaan media sebaiknya guru perlu mengetahui terlebih dahulu cara pengoperasian media tersebut secara benar agar tidak mudah mengalami kerusakan.

Pemeliharaan media pembelajaran yang ada di MAN Krecek diserahkan kebagian sarpras. Jadi mengenai kondisi media, biaya perawatan dan perbaikan dibuatkan laporan dan disetorkan ke kepala sekolah secara berkala. Sesuai hasil pengamatan observasi yang peneliti lakukan dari 6 LCD proyektor yang tersedia, ada 2 yang masih dalam proses perbaikan, ada permasalahan pada USBnya ungkap salah satu murid di lokasi.

Deskripsi di atas menunjukan bahwa pengawasan media pembelajaran yang dilakukan oleh waka kurikulum dan kepala sekolah di MAN Krecek yaitu secara administrative, tidak berarti kepsek setiap hari harus mengingatkan guru untuk memakai media pembelajaran.

27 Arsyad, Media pembelajaran, 10.

Dirasah, Vol. 2, No. 2, Agustus 2019 


\section{Penutup}

Berdasarkan hasil penelitian yang telah diuraikan penulis pada penyajian dan analisis data di atas, maka dapat disimpulkan sebagai berikut:

1. Perencanaan (Planning) pengembangan media pembelajaran di MAN Krecek dilakukan oleh guru berdasarkan RPP (pokok bahasan) dan dengan kebutuhan media pembelajaran yang sesuai.

2. Pengorganisasian (Organizing) media pembelajaran di MAN Krecek Pare Kediri di anggap baik karena didukung dengan guru yang professional sesuai kompetensi dan juga dengan media pembelajaran yang memadai (LCD, Komputer, gambar).

3. Pelaksanan (Actuating) pembelajaran dengan menggunakan media pembelajaran sudah bisa dikatakan baik, dikarenakan $90 \%$ guru menggunakan media dan didukung multi metode.

4. Pengawasan (Controlling) terhadap pengembangan media pembelajaran di MAN Krecek dilakukan oleh kepala sekolah dan waka kurikulum agar penggunaan media dapat dioptimalkan.

\section{Daftar Pustaka}

Arsyad, Azhar. Media Pembelajaran, Jakarta: PT. Rajawali Pers. 2015

Arikunto, Suharsimi. Pengelolaan Kelas dan Siswa Sebuah Pendekatan, Jakarta: CV. Rajawali. 1996

Djamarah, Syaiful Bahri dan Aswan Zein. Strategi Belajar Mengajar Jakarta: Rineka Cipta. 2006

Uno, Hamzah B. Perencanaan Pembelajaran, Jakarta: PT. Bumi Aksara. 2007

J.Lexy, Moleong. Metodologi Penelitian Kualitatif, Bandung: PT Remaja Rosdakarya. 2005

Majid, Abdul. Perencanaan Pembelajaran, Bandung: Rosda Karya. 2007

Rahadi, Aristo. Media Pembelajaran. Depdiknas Dirjend Pendidikan Dasar dan Menengah Direktorat Tenaga Kependidikan. 2003 
Susilana, Rudi \& Cepi Riana. Media Pembelajaran, Hakikat, Pengembangan, Pemanfaatan dan Penilaian. Bandung: CV Wacana Prima. 2009

Sugiono. Metode Penelitian Pendidikan Pendekatan Kuantitatif, Kualitatif,dan $R \& D$, Bandung: Alfabeta. 2013

Sugiyono. Metode Penelitian Pendidikan(Pendekatan Kuantitatif, Kualitatif dan $R \& D)$. Bandung: Alfabeta. 2010

Copyright (C) 2019 Journal Dirasah: Vol. 2, No. 1, Februari 2019, p-ISSN: 2615-0212, e-ISSN; 2621-2838

Copyright rests with the authors

Copyright of Jurnal Dirasah is the property of Jurnal Dirasah and its content may not be copied or emailed to multiple sites or posted to a listserv without the copyright holder's express written permission. However, users may print, download, or email articles for individual use.

https://ejournal.iaifa.ac.id/index.php/dirasah 